\title{
KARAKTERISASI CHITOSAN DAN CHITOSAN POLYMER MEDIUM DARI CANGKANG KEPITING BATU
}

\author{
Characterization of Chitosan and Chitosan Polymer Medium From Stone Crab's \\ (Grapsus albolineatus) Shells
}

\author{
Eko Cahyono, Stevy Imelda Murniati Wodi, Jumardi Tondais \\ Program Studi Teknologi Pengolahan Hasil Laut Politeknik Negeri Nusa Utara \\ Email: ekocahyono878@gmail.com
}

\begin{abstract}
Abstrak: Kepiting batu (Grapsus albolineatus) merupakan spesies yang banyak ditemukan di pantai berbatu dan eksoskeletonnya adalah salah sumber potensial chitin-chitosan. Chitosan adalah polimer bersifat polikationik dengan chitosan polymer medium (CPM) yang memiliki molekul lebih sederhana sebagai salah satu turunannya. Tujuan penelitian ini adalah untuk menentukan mutu chitosan dan chitosan polymer medium dari cangkang kepiting batu. Metode yang digunakan pada penelitian ini adalah metode eksperimental. Hasil analisis membuktikan bahwa cangkang kepiting memiliki komposisi 4.17 \pm 0.08 air, 54.4 \pm 2.78 abu, 6.28 \pm 0.05 lemak, 23.48 \pm 0.01 protein, $11.70 \pm 2.93$ kaborhidrat. Karakterisasi chitosan memperlihatkan rendemen sebesar $10 \pm 0.70 \%$, kadar air $8.10 \pm 0.14 \%$, abu $19.39 \pm 0.55 \%$, lemak $6.26 \pm 0.37 \%$, protein $8.24 \pm 0.34 \%$, karbodidrat $50.03 \pm 0.04 \%$, derajat putih $60.61 \pm 0.86 \%$, viscositas $7.30 \pm 0.42$ cps dan derajat deasetilasi $55.92 \pm 1.30 \%$. Untuk chitosan polymer medium, rendemennya mencapai $98.33 \pm 0.40 \%$ dan derajat deasetilasinya sebesar $60.22 \pm 0.24 \%$. Chitosan dan chitosan polymer medium dari cangkang kepiting batu (Grapsus albolineatus) masih memenuhi standar yang ditetapkan SNI.
\end{abstract}

Kata kunci: kepiting batu, kitosan, kitosan polimer medium

\begin{abstract}
Stone crab (Grapsus albolineatus) is a species commonly found in rocky beaches. Its exoskeleton is a good source of chitin and/or chitosan. Chitosan represents a polycationic polymer with chitosan polymer medium (CPM) having simpler molecular formula than chitosan as chitosan's derivative. The objective of this research was to determine the quality of chitosan and chitosan polymer medium from rock crab's shells. Experimental method was used in this study with characterization of the crab's shells showing a composition of $4.17 \pm 0.08 \%$, water, $54.4 \pm 2.78 \%$ ash, $6.28 \pm 0.05 \%$ fat, $23.48 \pm 0.01 \%$ protein and $11.70 \pm 2.93 \%$ carbohydrate. Similar characterization on chitosan revealed a composition of $10 \pm 0.70 \%$ rendemen, $8.10 \pm 0.14 \%$ water, $19.39 \pm 0.55 \%$ ash, $6.26 \pm 0.37 \%$ fat, $8.24 \pm 0.34 \%$ protein, $50.03 \pm 0.04 \%$ charabohydrate, $60.61 \pm 0.86 \%$ white degree, $7.30 \pm 0.42$ cps viscosity and $55.92 \pm 1.30 \%$ degrees of deacetylation. Although chitosan contained similar composition of white degree $(60 \%)$ and deactylation $(60 \% 0$ to chitoxan polymer medium, CPM had higher composition of rendemen $(98.33 \pm 0.40 \%)$ than chitosan (10 $\pm 0.70 \%)$. In conclusion, this study shows that chitosan and chitosan polymer medium of $G$. albolineatus met our national standard (SNI).
\end{abstract}

Keyword: chitosan, chitosan polymer medium, stone crab 


\section{PENDAHULUAN}

Kepiting batu (Grapsus albolineatus) merupakan spesies berwarna hitam kehijauan yang ditemukan di pantai berbatu. Ciri khas kepiting batu termasuk (1) memiliki kaki jalan yang panjang, (2) tidak memiliki kaki renang, (3) memiliki capit berukuran kecil, dan (4) capit berwarna ungu. Kepiting batu memiliki warna menarik pada organ karapas yang mengindikasikan pigmen (Makalalag et al. 2017). Berdasarkan studi empiris, kepiting batu memiliki jumlah sangat melimpah di Kepulauan Sangihe khususnya di sepanjang Teluk Tahuna, Kepulauan Tinakareng dan Pelabuhan perdagangan Petta. Meskipun kepiting ini umumnya tidak memiliki nilai ekonomis, cangkang kepiting ini punya nilai jual karena merupakan sumber chitin-chitosan.

Dengan struktur [ $\beta$-(1-4)- 2-amina -2-deoksi D-glukosa], chitosan adalah hasil deasetilasi dari chitin. Chitosan merupakan suatu polimer yang bersifat polikationik. Keberadaan gugus hidroksil dan amino berada di sepanjang rantai polimer (Anas et al 2018). Lebih lanjut Sugiyanti et al. (2018) menyatakan bahwa chitosan merupakan biopolymer alami terbanyak kedua setelah selulosa, yang terdapat di alam dan dapat diaplikasikan dalam bidang pangan dan kesehatan. Chitosan dapat dimanfaatkan sebagai antibakteri (Suherman et al. 2018), penjernih air (Mustafiah et al. 2018), antikanker (Ibrahim dan Lim 2018), edible coating (Ventura-Aguilar et al. 2018). Chitosan dapat dimanfaatkan lebih lanjut sebagai (CPM) dengan cara memotong polimer rantai panjang menjadi chitosan polymer medium.

Chitosan polymer medium (CPM) merupakan salah satu bentuk turunan chitosan, diperoleh dengan cara pengecilan polimer panjang menggunakan magnetic stirrer dimana jumlah monomernya menjadi lebih pendek. Pembuatan CPM ini menggunakan konsentrasi asam asetat $1 \%$ sebanyak $100 \mathrm{~mL}$ (Mardani 2015). Berdasarkan uraian dari latar belakang di atas maka perlu dilakukan karakterisasi chitosan dan chitosan polymer medium.

\section{METODE PENELITIAN}

\section{Alat dan Bahan}

Alat yang digunakan antara lain erlenmeyer $1000 \mathrm{~mL}$, beaker gelas $1000 \mathrm{~mL}$, timbangan, kompor listrik, sudip, oven pengering, $\mathrm{pH}$ meter, magnetic stirrer, gelas ukur $100 \mathrm{~mL}$, wadah (loyang) dan hot plate, desikator dan cawan porselin. Bahan yang digunakan kepiting batu (Grapsus albolineatus), $\mathrm{NaOH}$ $1 \mathrm{~N}, \mathrm{HCl} 1 \mathrm{~N}, \mathrm{NaOH} 30 \mathrm{~N}, \mathrm{CH}_{3} \mathrm{COOH} 1 \mathrm{~N}$ dan aquadest.

\section{Ekstraksi Chitosan (Cahyono 2018)}

Proses pembuatan chitosan terdiri dari 3 tahap yaitu deproteinasi, demineralisasi dan deasetilasi. Tahap deproteinasi menggunakan $\mathrm{NaOH}$ konsentrasi 1 $\mathrm{N}$. Tahap demineralisasi menggunakan $\mathrm{HCl}$ konsentrasi $1 \mathrm{~N}$. Tahap deasetilasi menggunakan $\mathrm{NaOH}$ dengan konsentrasi $20 \mathrm{~N}$.
Ekstraksi Chitosan Polimer Medium (Mardani 2015) modifikasi

Sampel chitosan ditimbang sebanyak $5 \mathrm{~g}$. Larutkan chitosan pada Asam asetat $1 \mathrm{~N}(1: 100 \mathrm{~b} / \mathrm{v})$. Sampel dipanaskan menggunakan hot plate pada suhu $\pm 40{ }^{\circ} \mathrm{C}$. Sampel diaduk menggunakan magnetic stirrer selama \pm 1 jam. Tambahkan asam asetat $1 \mathrm{~N}$ sebanyak $400 \mathrm{~mL}$ sehingga total larutan menjadi $500 \mathrm{~mL}$. Pemotongan polymer dilakukan dengan menggunakan magnetic stirrer selama \pm 10 menit pada suhu $\pm 40^{\circ} \mathrm{C}$. Proses presipitasi dilakukan dengan larutan $\mathrm{NaOH} 1 \mathrm{~N}$. Sampel dicuci menggunakan aquadest hingga $\mathrm{pH}$ netral. Sampel dikeringkan pada suhu $80{ }^{\circ} \mathrm{C}$ selam \pm 6 jam.

\section{Parameter Pengujian}

Parameter uji dalam penelitian ini meliputi kadar air, kadar abu, kadar lemak, kadar protein, karbohidrat, viscositas, darajat putih, dan darajat deasetilasi menggunakan metode AOAC (2005).

\section{Analisa Data}

Data yang diperoleh selanjutnya dianalisis secara deskriptif untuk menginterpretasikan hasil penelitian yang telah diperoleh baik dalam bentuk gambar maupun tabel.

\section{HASIL DAN PEMBAHASAN}

\section{Karakterisasi Cangkang Kepiting}

Cangkang kepiting adalah lapisan keras terluar dari tubuh kepiting dengan karakteristik seperti tersaji pada Tabel 1.

Tabel 1. Karakterisasi cangkang kepiting

\begin{tabular}{lcc}
\hline \multicolumn{1}{c}{ Parameter } & $\begin{array}{c}\text { Data } \\
\text { Penelitian }\end{array}$ & $\begin{array}{c}\text { Humairah } \\
(\mathbf{2 0 1 7})\end{array}$ \\
\hline Kadar air (\%) & $4.17 \pm 0.08$ & 5.39 \\
Kadar abu (\%) & $54.4 \pm 2.78$ & 57.56 \\
Kadar lemak (\%) & $6.28 \pm 0.05$ & 2.38 \\
Protein (\%) & $23.48 \pm 0.01$ & 14.11 \\
Karbohidarat (\%) & $11.70 \pm 2.93$ & 26.25 \\
\hline
\end{tabular}

\section{Kadar Air}

Cangkang kepiting hasil penelitian memiliki kadar air $4.17 \pm 0.08 \%$. Kadar air merupakan suatu parameter yang sangat penting untuk menentukan mutu cangkang kepiting (Tondais et al. 2020). Kadar air yang rendah dapat menekan atau mengurangi kerusakan cangkang kepiting, seperti terhindar dari adanya aktivitas mikroorganisme akibat kelembaban. Menurut Humairah (2017) kadar air cangkang kepiting sebesar 5.39\%. Kadar air yang rendah diduga akibat pengeringan dengan suhu tinggi sehingga air yang terkandung dalam bahan berkurang.

\section{Kadar Abu}

Pada Tabel 1 menunjukkan bahwa kadar abu cangkang kepiting dari hasil penelitian $54.4 \pm 2.78 \%$. Kadar abu merupakan suatu parameter untuk mengetahui mineral yang ada pada limbah cangkang kepiting. Menurut Nduru et al. (2018) abu adalah residu organik dari pembakaran komponen organik 
sedangkan mineral merupakan komponen penyusun abu yang terdapat dalam proporsi yang berbeda-beda tergantung jenis bahan organiknya. Menurut Humairah (2017) kadar abu cangkang kepiting adalah 57.26\%; Nduru et al. (2018) 51.00\%.

\section{Lemak}

Lemak pada cangkang kepiting hasil penelitian $6.28 \pm 0.05 \%$. Lemak merupakan senyawa organik yang terdapat di alam tidak larut dalam air, namun larut dalam pelarut organik non-polar, seperti dietil eter, kloroform, benzena serta hidrokarbon lainnya. Menurut Humairah (2017) Lemak yang ada pada cangkang kepiting yaitu $2.38 \%$. Tingginya lemak dikarenakan adanya pigmen dan sisa daging yang masih menempel pada cangkang.

\section{Protein}

Protein cangkang kepitng penelitian $23.48 \pm 0.01 \%$. Protein adalah senyawa organik kompleks berbobot mempunyai molekul tinggi yang merupakan polimer dari monomer asam amino yang dihubungkan satu sama lain dengan satu ikatan peptida. Menurut Maidin (2017) secara umum cangakang kepiting mengandung protein antara $15.60 \%-23.90 \%$.

\section{Karbohidrat}

Karbohidrat yang terkandung dalam cangkang kepiting hasil penelitian $11.70 \pm 2.93 \%$. Karbohidrat merupakan zat gizi sebagai sumber utama yang sangat penting bagi seluruh makhluk hidup karena molekulnya menyediakan unsur karbon yang dapat dipergunakan oleh sel. Menurut Siregar (2017) karbohidarat adalah salah satu zat gizi yang diperlukan oleh seluruh makhluk hidup yang berfungsi untuk menghasilkan energi. Menurut Humairah (2017) Karbohidrat yang terkandung dalam cangkag kepiting adalah $26.25 \%$.

\section{Karakterisasi Chitosan}

Chitosan adalah suatu biopolymer dengan struktur [ $\beta$-(1-4)-2-amina -2-deoksi -D-glukosa] yang dihasilkan dari suatu proses deasetilasi kitin dengan menggunakan larutan basa kuat. Menurut Rani et al. (2018) Chitosan adalah senyawa yang bersifat polikationik dengan rumus kimia poli (2-amino-2dioksi- $\beta$-D-Glukosamin) yang dapat dihasilkan melalui proses hidrolisis chitin dengan menggunakan basa kuat. Chitosan memiliki karakterisasi yaitu dapat dilihat pada Tabel 2.

Tabel 2. Karakterisasi Chitosan

\begin{tabular}{lcccc}
\hline Parameter & Data Penelitian & EFSA (2010) & GRAS (2012) & SNI (2013) \\
\hline Rendemen (\%) & $10 \pm 0.71$ & - & - & - \\
Kadar Air (\%) & $8.10 \pm 0.14$ & $\leq 10$ & $\geq 10$ & $\leq 12$ \\
Kadar Abu (\%) & $19.39 \pm 0.55$ & $\leq 3$ & $\leq 0.5$ & $\leq 5$ \\
Kadar Lemak (\%) & $6.26 \pm 0.37$ & $\leq 1$ & - & - \\
Kadar Protein (\%) & $8.24 \pm 0.34$ & $\leq 6$ & $0.02 \mathrm{~g} / 100 \mathrm{~g}$ & - \\
Karbohidrat *) (\%) & $58.03 \pm 0.44$ & - & - & - \\
Derajat Putih (\%) & $60.61 \pm 086$ & - & White powder & Coklat muda \\
Viscositas (cPs) & $7.30 \pm 0.42$ & - & $25-5.000$ & - \\
Derajat Deasetilasi (\%) & $55.92 \pm 1.30$ & $\geq 90$ & $75-95$ & $\geq 75$ \\
\hline
\end{tabular}

Keterangan: *) by difference

\section{Rendemen}

Rendemen adalah perbandingan jumlah chitosan yang dihasilkan dari ekstraksi cangkang kepiting batu (Grapsus albolineatus). Menurut Lalenoh dan Cahyono (2018) rendemen merupakan salah satu parameter yang penting dalam proses pembuatan chitosan. Rendemen chitosan penelitian $10 \pm 0.71 \%$. Menurut Supriyantini et al. (2018) rendemen chitosan berdasarkan berat chitosan yang dihasilkan dibagi dengan berat chitin yang diperoleh dari penelitian yaitu $10 \pm 0.71 \%$. Rendemen yang rendah pada hasil penelitian dapat dipengaruhi oleh konsentrasi $\mathrm{NaOH}$ yang tinggi, dikarenakan proses penetralannya memakan waktu yang cukup lama sehingga jumlah rendemen semakin berkurang. Menurut Widia et al. (2018) Rendemen yang rendah disebabkan oleh prosesproses pembuatan chitosan. Prosen ini menyebabkan sebagian komponen seperti mineral, protein dan gugus asetil yang terdapat dalam bahan hilang, sehingga menyebabkan rendemen chitosan rendah. Perbedaan nilai rendemen chitosan yang dihasilkan diduga dipengaruhi oleh proses pemutusan ikatan asetil pada proses hidrolisis chitosan yang menyebabkan penurunan ukuran molekul sehingga bobot molekul chitosan menjadi lebih ringan (Syukron 2016).

\section{Kadar Air}

Kadar air merupakan suatu parameter untuk menentukan mutu chitosan. Mutu chitosan dipengaruhi oleh rendahnya kadar air yang tekandung dalam chitosan. Kadar air yang rendah dapat menghabat dan mengurangi kerusakan pada chitosan, misalnya dapat terhindar dari adanya aktivitas mikroorganisme yang disebabkan oleh tingkat kelembaban. Menurut Yanti et al. (2018) Kadar air merupakan salah satu parameter yang sangat penting untuk menentukan kualitas chitosan, kadar air yang rendah dapat menekan serta mengurangi kerusakan pada chitosan, seperti terhindar dari suatu aktivitas mikroorganisme yang dapat dipengaruhi oleh kelembaban. Chitosan yang dihasilkan dari penelitian memiliki kadar air sebesar $8.10 \pm 0.14 \%$. Kadar air chitosan hasil penelitian masih berada di dalam standar mutu yang ditetapkan EFSA (2010) yaitu $\leq 10$. 


\section{Kadar Abu}

. Kadar abu chitosan dari hasil penelitian adalah $19.39 \pm 0.55 \%$. Kadar abu merupakan campuran dari komponen anorganik dan mineral yang terkandung dalam suatu bahan pangan. Menurut Siregar et al. (2016) kadar abu merupakan parameter untuk mengetahui mineral yang ada dalam suatu bahan yang mencirikan keberhasilan proses demineralisasi yang dilakukan. Menurut Cahyono et al (2018) kadar abu chitosan merupakan suatu parameter yang utama untuk menentukan mutu chitosan karena bebera residu abu dari chitosan dapat mepengaruhi ciri khas yang lebih penting lainnya dari produk akhir. Menurut Widia et al. (2018) kadar abu chitosan merupakan indikator keefektifan dari tahap demineralisasiChitosan yang dihasilkan dari penelitian memiliki kadar abu yang sangat tinggi melebihi batas maksimum standar mutu kadar abu chitosan yang ditetapkan EFSA (2010) $\leq$ $3 \%$; GRAS $(2012) \leq 0.5 \%$; SNI $(2013) \leq 5 \%$.

\section{Lemak}

Lemak chitosan dari hasil penelitian sebesar $6.26 \pm 0.37 \%$. Lemak merupakan suatu kelompok organik yang tidak larut dalam air. Menurut Sanusi dan Widiyanto (2018) lemak lebih banyak disimpan pada umumnya di bawah kulit (jaringan adipose), jaringan otot serta pada bagian tubuh tertentu seperti perut, lengan, paha dan pinggul. Menurut Gintu et al. (2014) kadar lemak yang terkandung dalam chitosan hasil penelitian yaitu $2.09 \%$. Lebih lanjut menurut Cahyono (2018) kadar lemak yang terkandung dalam chitosan hasil penelitian yaitu sebesar $3.13 \%$. Tingginya kadar lemak yang terkandung dalam chitosan hasil penelitian disebabkan konsentrasi basa kuat pada proses deproteinase serta konsentrasi asam kuat pada proses demineralsasi.

\section{Protein}

Protein merupakan suatu senyawa yang dibutuhkan dalam tubuh manusia sebagai zat pendukung pertumbuhan dan perkembangan (Cahyono dan Mardani 2020). Protein chitosan dari hasil penelitian yaitu $8.24 \%$. Menurut Edward et al. (2016) dari hasil penelitian yang dilakukan protein yang terkandung dalam chitosan adalah $0.29 \%$. Lebih lanjut menurut Gintu et al. (2014) kadar protein yang terkandung dalam chitosan dari hasil penelitian yaitu sebesar $8.24 \pm 0.34 \%$. Tingginya protein yang terkandung dalam chitosan hasil penelitian diduga proses deproteinase yang kurang sempurna.

\section{Karbohidrat}

. Karbohidrat yang terkandung dalam chtiosan dari hasil penelitian yaitu $58.03 \pm 0.44 \%$. Karbohidrat adalah suatu senyawa organik yang terdiri dari unsur karbon, hydrogen dan oksigen. Menurut Siregar (2017) karbohidrat sebagai zat gizi merupakan nama kelompok zat-zat organik yang mempunyai struktur molekul yan berbeda-beda, meski terdapat persamaanpersamaan dari sudut kimia dan fungsinya. Fungsi karbohidrat yang paling utama adalah untuk menghasilkan energi Menuurt hasil penelitian Cahyono (2018) karbohidrat yang terkandung dalam chitosan sebesar $81.39 \%$. Kadar karbohidat hasil penelitian sangat rendah dibandingkan dengan hasil penelitian Cahyono (2018).

\section{Derajat Putih}

Derajat putih merupakan tingkatan warna putih yang dimiliki oleh suatu bahan. Menurut Prinaldi et al. (2018) analisis derajat putih dilakukan untuk mengukur tingkat warna putih suatu material. Tingkat derajat putih chitosan pada hasil penelitian adalah $60.61 \pm 086 \%$. Menurut Cahyono (2018) chitosan dari hasil penelitian berwarna putih kecoklatan. Chitosan dari hasil penelitian memiliki warna kuning pucat. Perubahan warna pada chitosan diduga karena perlakuan menggunakan $\mathrm{NaOH}$ dan pemanasan mengakibatkan perubahan warna chitosan menjadi kuning pucat. Menurut Stefunny et al. (2016) Chitosan dari hasil penelitian yaitu berwarna putih.

\section{Viskositas}

Viskositas chitosan dari hasil penelitian adalah $7.30 \pm 0.42 \mathrm{cPs}$. Viskositas merupakan salah satu sifat atau karakteristik suatu bahan. Menurut Siregar $e t$ al. (2016) larutan chitosan merupakan senyawa kimia berupa rantai-rantai polimer yang mempunyai viskositas tinggi. Chitosan dari hasil preparasi dalam penelitian memiliki viskositas 109.11-161.78 cPs. Viskositas chitosan dapat diukur dengan cara melarutkan $1 \%$ kitosan ke dalam larutan asam asetat $1 \%$ kemudian diukur viskositasnya dengan alat viscometer (Siregar et al. 2016). Lebih lanjut lagi menurut hasil penelitian Cahyono (2018) viskositas chitosan dari hasil penelitian adalah 1.713,04 cPs. Viskositas diukur dengan viskometer ubbelohde pada kecepatan $50 \mathrm{rpm}$ menggunakan spindle nomor 2 selama 1 menit.

\section{Derajat Deasetilasi (DD)}

Deasetilasi merupakan proses untuk menghilangkan gugus asetil yang ada pada bahan (Cahyono et al. 2019). Menurut Safitri et al. (2016) deasetilasi adalah proses pembentukan chitosan dari kitin dengan menggunakan larutan basa kuat $\mathrm{NaOH}$ untuk mengganti gugus asetamida dengan gugus amino. Lebih lanjut Menurut Widia et al. (2018) derajat deasetialasi merupakan salah satu karakteristik kimia yang paling penting karena mempengaruhi kemampuan chitosan pada berbagai aplikasinya. Proses deasetilasis bertujuan untuk memutuskan ikatan kovalen antara gugus asetil dengan nitrogen pada gugus asetamida kitin menghasilkan gugus amina terdeasetilasi. Penghilangan gugus asetil yang berada pada gugus asetamida chitin yaitu dikenal dengan istilah DD (Mursida et al. 2018). Derajat deasetilasi chitosan hasil penelitian adalah $55.92 \pm 1.30 \%$. Menurut Cahyono (2018) DD chitosan dari hasil penelitian yaitu 98.65\%. Spektrum FTIR (Fourier Transform Infrared) chitosan hasil penelitian dapat dilihat pada Gambar 4. 


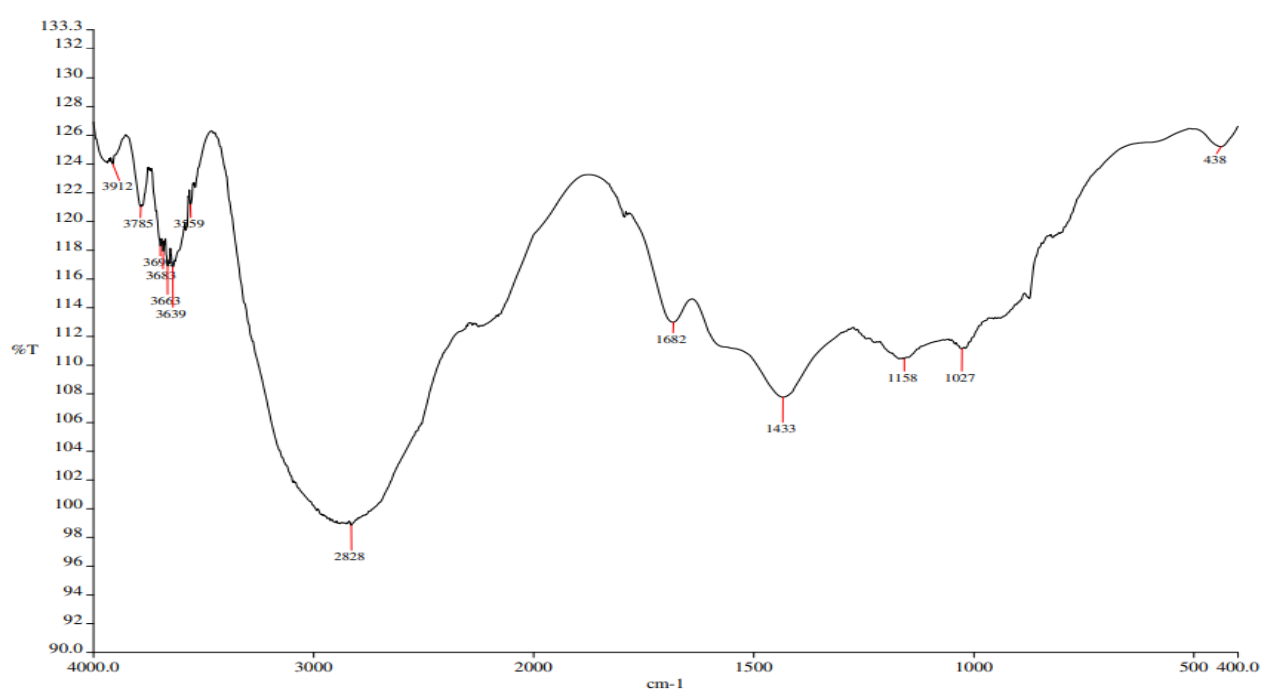

Gambar 4. Spektrum FTIR (Fourier Transform Infrared) Chitosan

\section{Karakterisasi Chitosan Polimer Medium}

Chitosan polimer medium adalah salah satu bentuk turunan dari chitosan, diperoleh dengan cara pengecilan polymer panjang menggunakan magnetic stirrer dimana jumlah monomernya menjadi lebih pendek (Mardani 2015). Chitosan polimer medium memiliki karakterisasi dapat dilihat pada Tabel 3.

Tabel 3. Karakterisasi chitosan polimer medium

\begin{tabular}{lcc}
\hline \multicolumn{1}{c}{ Parameter } & $\begin{array}{c}\text { Data } \\
\text { Penelitian }\end{array}$ & $\begin{array}{c}\text { Mardani } \\
\mathbf{2 0 1 5}\end{array}$ \\
\hline Rendemen (\%) & 98.33 & - \\
Derajat Deaasetilasi (\%) & 60.22 & 92.60 \\
\hline
\end{tabular}

\section{Rendemen}

Rendemen merupakan suatu perbandingan jumlah chitosan polimer medium dibahagi dengan berat chitosan yang diperoleh dari penelitian. Rendemen chitosan polimer medium hasil penelitian adalah 98.33\%. Tingginya rendemen yang dihasilkan disebabkan oleh konsentrasi asam asetat yang rendah sehingga proses penetralanya tidak memakan waktu yang cukup lama. Jika proses penetralannya memerlukan waktu yang lama maka rendemen chitosan polimer medium semakin kecil. Kecilnya rendemen yang dihasilkan disebabkan oleh konsentrasi asam asetat yang sangat tinggi.

\section{Derajat Deasetilasi (DD)}

Derajat deasetilasi adalah suatu parameter lepasnya suatu gugus aseti dari kitin (Cahyono 2018). Derajat deasetilasi CPM ditentukan dengan mengguanakan spectrum inframerah. Frekuensi yang digunakan berkisar antara $4000 \mathrm{~cm}-1$ sampai dengan $400 \mathrm{~cm}-1$. Derajat deasetilasi CPM ditentukan dengan metode baseline (Mardani 2015). Derajat deasetilasi chitosan polimer medium dari hasil penelitian dihitung dengan menggunakan metode baseline. Metode ini dilakukan agar dapat mengetahui DD chitosan polimer medium dengan cara mengukur peak bagian bawa dan peak bagian atas dengan menggunakan mistar. Dari hasil pengukuran gelombang spektrum inframerah kemudian dilakukan penghitungan agar dapat mengetahui DD chitosan polimer medium. Derajat deasetilasi chitosan polimer medium dari hasil perhitungan yaitu sebesar $45.15 \%$. Spektrum FTIR (Fourier Transform Infrared) chitosan polymer medium dapat dilihat pada Gambar 5. 


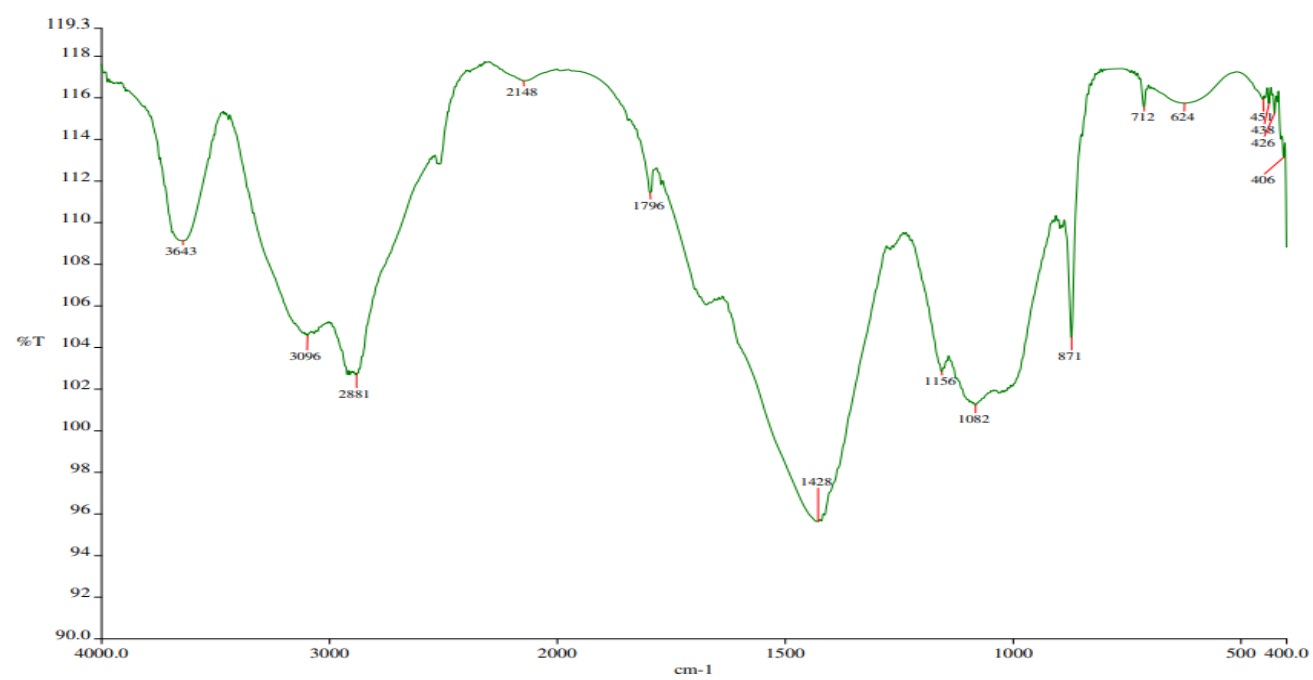

Gambar 5. Spektrum FTIR Chitosan Polimer Medium

\section{Kesimpulan}

Berdasarkan hasil penelitian dapat dikesimpulan bahwa chitosan dan chitosan polymer medium dari cangkang kepiting batu (Grapsus albolineatus) masih memenuhi standar yang ditetapkan SNI.

\section{Saran}

Untuk penelitian selanjutnya dapat disarankan pembuatan chitosan dan chitosan polimer medium menggunakan metode hidrolisis bertekanan agar lebih aman dan menghasilkan chitosan dan chitosan polimer medium yang sesuai standar mutu panagan dan farmasi.

\section{DAFTAR PUSTAKA}

AOAC] Association of Official Analytical Chemists. 2005. Official Methods of Analysis. 18thed. Maryland: Association of Official Analytical Chemists Inc.

Anas A, Ahzan S, Sabda Budi P D. 2018. Pembuatan Filter Penangkap Eas (Au) Menggunakan Kitin Dan Kitosan Dari Cangkang Kepiting. Pendidikan Fisika. 5 (2):23-30.

Cahyono E. 2018. Karakteristik Kitosan dari Lmbah Kulit Udang Windu (Panaeus monodon). Jurnal Akuatika Indonesia. 3(2): 96-102.

Cahyono E, Wodi SIM, Kota N. 2018. Aplikasi Kitosan Kulit Udang Windu (Panaeus monodon) Sebagai Pengawet Alami Pada Tahu. Jurnal Ilmiah Tindalung. 4(1):41-44

Cahyono E, Jonas JF, Lalenoh BA, Kota N. 2019. Karakterisasi Kalsium Karbonat (CaCO3) Dari Cangkang Landak Laut (Diadema setosum). Jurnal FishtecH. 8(1):28-34

Cahyono E, Mardani I. 2020. Identifikasi Asam Amino Ikan Layang (Decapterus russelli) Pada Lokasi Penangkapan Berbeda. Jurnal Pengolahan Pangan. 5(1):1-6.

Edward J, Dompeipen, Kaimudin M, Riardi P, Dewa. 2018. Isolasi Kitin dan Kitosan dari Limbah
Kulit Udang. Jurnal Kementrian Perindustrian. 12(1): 32-38.

[EFSA] European Food Safety Authority. 2010. Scientific opinion on the safety of chitinglucan as a novel food ingredient. European Food Safety Authority. 8(7):1-17.

Gintu R A, Soetjipto H, Cahyanti N. M. 2014. Karakterisasi dan Sifat Fisikokimia Kitosan dari Kulit Udang. [Makalah Paralel]. Fakultas Sains dan Matematika. Universitas Kristen Satya Wacana.

[GRAS] Generally Recognized As Safe. 2012. Chitoclear ${ }^{\circledR}$ shrimp derived chitosan: food usage conditions for general recognition of safety. Iceland (IL): GRAS

Humairah S. 2017. Komposisi Kimia Tepung Cangkang Kepiting Bakau (Scylla sarrata). Jurnal Online Mahasiswa. Pekan baru. FPK UNRI.

Ibrahin AFM dan Lim YS. 2018. Synthesis of graphene oxide membranes on polyester substrate by spray coating for gas separation. Chemical Engineering Science. 190(23): 312-319

Lalenoh B dan Cahyono E. 2018. Karakterisasi Kitosan dari Limbah Rajungan (Portunus pelagicus). Jurnal Ilmiah Tindalung. 4(1): 30-33.

Maidin N A. 2017. Produksi Kitosan dari Limbah Cangkang Kepiting Rajungan (Portunidae) Secara Enzimatis dan Aplikasinya sebagai Penurun Kolestrol. [Tesis]. Universitas Hasanuddi Makasar.

Makalalag S, Saadah J D. Paransa1, M H D. Mantiri. 2017. Penentuan Kandungan Pigmen Karotenoid Pada Kepiting Grapsus Albolineatus (Lamarck) Betina Dari Perairan Pesisir Pantai Desa Tanawangko. Pesisir Dan Laut Tropis. 3(1).1-9.

Mardani I. 2015. Masker Chitosan Polymer Medium Pereduksi Asap Rokok dan Emisi Kendaraan Bermotor. [Skripsi]. Teknologi Hasil Perairan. Institut Pertanian Bogor. 
Mursida, Tasir, Sahriawati. 2018. Efektifitas Larutan Alkali Pada Proses Deasetilasi Dari Berbagai Bahan Baku Kitosan. Jurnal Pengolahan Hasil Perikanan Indonesia. 21(2):356-366.

Mustafiah, Darnengsih D, Sabara Z, Abdul Majid R. 2018. Pemanfaatan Kitosan Dari Limbah Kulit Udang Sebagai Koagulan Penjernihan Air. Journal of Chemical Process Engineering. 3(1):27-32.

Nduru A M F, Drastinawati, Yenti R S. 2018. Isolasi Kitin dari Limbah Cangkang Kepiting (Scylla $s p)$ dengan Variasi Pelarut pada Proses Bleaching. [Jom FTEKNIK]. 5(1): 1-6.

Prinaldi V W, Suptija P dan Uju. 2018. Karakteristik Sifat Fisikokimia Nano-Kalsium Ekstrak Tulang Ikan Tuna Sirip Kuning (Thunnus Albacares). Jurnal Pengolahan Hasil Perikana Indonesia. 21(3): 385-395.

Rani A, Drastinawati, Yusnimar. 2018. Sintesis Kitosan Dari Limbah Cangkang Kepiting Dengan Variasi Konsentrasi Naoh Dan Kecepatan Pengadukan. [Jom FTEKNIK]. 5(2): $1-5$.

Safitril D R N, Dali S, Fawwaz M. 2016. Isolasi Kitosan Dari Limbah Cangkang Kepiting Bakau (Scylla Serrata) dan Aplikasinya Terhadap Penyerapan Trigliserida. 8(2): 20-27.

Sanusi R, Widiyanto W. 2018. Pengembangan model aquarobic exercise untuk pembakaran lemak pada overweight. Jurnal Keolahragaan. 6(2):139-149

Siregar C E, Suryatil dan Hakim L. 2016. Pengaruh Suhu Dan Waktu Reaksi Pada Pembuatan Kitosan Dari Tulang Sotong (Sepia officinalis). Jurnal Teknologi Kimia Unimal. 5(2): 37-44.

[SNI] Standarisasi Nasional Indonesia. 2013. Kitosan: syarat mutu dan pengolahan. Jakarta (ID): Badan Standardisasi Nasional.

Stefunny, Zaharah A T, Harlia. 2016. Sintesis, Karakterisasi Dan Aplikasi Kitosan Dari Cangkang Udang Wangkang (Penaeus orientalis) Sebagai Koagulan Dalam Menurunkan Kadar Bahan Organik Pada Air Gambut. [JKK]. 5(3): 52-59.
Sugiyanti D, Darmadji P, Santoso U, Pranoto Y, Anwar C, Anggrahini S. 2018. Biological Activity of Native and Low Molecular Weight Chitosan obtained by Steam Explosion Process. Pak J Biol Sci .21(9):441-447.

Suherman B, Muhdar L, Dewi Rosmala Teresia S. 2018. Potensi Kitosan Kulit Udang Vannemei (Litopenaeus Vannamei) Sebagai Antibakteri Terhadap Staphylococccus Epidermidis, Pseudomonas Aeruginosa, Propionibacterium Agnes, Dan Escherichia Coli Dengan Metode Difusi Cakram Kertas. Farmasi Poltekkes Kemenkes Makassar. 14 (1):116-127.

Supriyantini E, Yulianto B, Ridlo A, Sedjati S , Caesario Nainggolan A . 2018. Pemanfaatan Chitosan Dari Limbah Cangkang Rajungan (Portunus pelagicus) sebagai Adsorben Logam Timbal (Pb). Kelautan Tropis. 21(1):23-28.

Tondais J, Sombo DE, Lalenoh BA, Mappiratu M, Adrian A, Cahyono E. 2020. Ekstraksi Flavour dari Tepung Ikan Layang (Decapterus sp.) Menggunakan Enzim Protease Biduri (Calotropis gigantea). Jurnal FishtecH. 9(1):612

Ventura-Aguilar RI, Baños S. B, García G. F, Avejar L. Z. 2018. Impact of chitosan based edible coatings functionalized with natural compounds on Colletotrichum fragariae development and the quality of strawberries. Food Chemistry. 262 (1):142-149.

Widia, Sukmiwati M, Karnila R. 2018. Potensi Antioksidan Pada Kitosan Cangkang Kepiting Bakau (Scylla Serrata) Denganpenambahan Naoh Berbeda. Fakultas Perikanan Dan Kelautan. Universitas Riau Pekanbaru.

Yanti R, Drastinawati, Yusnimar. 2018. Sintesis Kitosan Dari Limbah Cangkang Kepiting Dengan Variasi Suhu Dan Waktu Pada Proses Deasetilasi. [Jom FTEKNIK]. 5(2): 1-7. 